\title{
Oxidation of Thiosulfate by a New Bacterium, Bosea thiooxidans (strain BI-42) gen. nov., sp. nov.: Analysis of Phylogeny Based on Chemotaxonomy and 16S Ribosomal DNA Sequencing
}

\author{
SUBRATA K. DAS, ${ }^{1}$ AJIT K. MISHRA, ${ }^{1 *}$ BRIAN J. TINDALL, ${ }^{2}$ FRED A. RAINEY, ${ }^{2}$ \\ AND ERKO STACKEBRANDT ${ }^{2}$ \\ Department of Microbiology, Bose Institute, CIT Scheme VII-M, Calcutta 700 054, India, ${ }^{1}$ and DSM-Deutsche \\ Sammlung von Mikroorganismen und Zellkulturen GmbH, D-38124 Braunschweig, Germany ${ }^{2}$
}

\begin{abstract}
A gram-negative bacterium which was capable of oxidizing reduced inorganic sulfur compounds was isolated from agricultural soil and designated BI-42. This new isolate grew on a wide range of organic substrates but was not able to grow autotrophically and lacked ribulose 1,5-bisphosphate carboxylase, a key enzyme of carbon dioxide fixation. These results suggested that strain BI-42 was a chemolithoheterotroph. Ammonia and nitrate were not used as sole nitrogen sources for growth, and strain BI-42 lacked glutamate synthase activity, which resulted in glutamate auxotrophy. The glutamate dehydrogenase activity of this organism was apparently insufficient for ammonia assimilation. On the basis of the results of additional biochemical tests, the $G+C$ content of the DNA, the results of a respiratory ubiquinone analysis, the results of a $16 S$ ribosomal DNA sequence analysis, the fatty acid composition, and the results of a membrane lipid analysis, strain BI-42 was identified as a phylogenetically and physiologically distinct taxon belonging to the alpha subclass of the Proteobacteria. Bosea thiooxidans gen. nov., sp. nov. is the name proposed for this taxon.
\end{abstract}

Sulfate is the end product of oxidations of reduced sulfur compounds by chemosynthetic, photosynthetic, and various heterotrophic microorganisms. Nature balances these oxidations through the biological reduction of sulfate to sulfide. Microorganisms utilize sulfur compounds for the biosynthesis of cellular material or transform these compounds as part of a respiratory energy-generating process. Most of the known sulfur-oxidizing bacteria belong to the genera Thiobacillus, Thiothrix, Beggiatoa, Thiomicrospira, Achromatium, Desulfovibrio, Desulfomonas, Desulfococcus, and Desulfuromonas $(18,55)$. Members of the genus Thiobacillus have been studied extensively to increase our understanding of the coupling of oxidation of reduced inorganic sulfur compounds to energy biosynthesis and assimilation of carbon dioxide (45). In addition, some phototrophic bacteria, such as members of the genus Chromatium, oxidize reduced inorganic sulfur compounds to provide reducing power for carbon dioxide assimilation during anaerobic photosynthesis (38).

However, oxidation of sulfur compounds is not restricted to the true sulfur bacteria; this process also occurs in heterotrophic bacteria isolated from soil (54) and the marine environment $(50,51)$. Most of the heterotrophic bacteria that have such activities belong to the genera Pseudomonas (35), Mycobacterium, Arthrobacter, Flavobacterium (54), and Xanthobacter or are Escherichia coli strains (42). However, few of these heterotrophs have the ability to generate biologically useful energy from the oxidation of reduced sulfur compounds (31). An exception is Paracoccus denitrificans (6), which also grows autotrophically in the presence of thiosulfate. Only a few heterotrophic bacteria, such as Thiobacillus sp. strain Q (8) and Catenococcus thiocyclus (39), have been shown to obtain energy from the oxidation of sulfur compounds. This type of nutrition has been designated chemolithoheterotrophy.

\footnotetext{
* Corresponding author. Present address: B-9/7, East Calcutta Township Project, Phase-III, E. M. Bypass, Calcutta 700 078, India. Phone: 91-33-442-1008. Electronic mail address: misra@boseinst.ernet .in.
}

Because of the potential importance of chemolithoheterotrophs in soil, attempts were made to isolate chemolithoheterotrophic bacteria from soil by enrichment culture techniques. A single strain was isolated from agricultural field soil, and this strain was designated BI- $42^{\mathrm{T}}$. Strain BI-42 oxidizes reduced inorganic sulfur compounds only in the presence of some organic substrates. In this paper we describe the isolation of this organism, its morphological and biochemical characteristics, its phylogenetic position based on the results of a $16 \mathrm{~S}$ ribosomal DNA (rDNA) sequence analysis, its chemotaxonomic properties, and its mode of thiosulfate utilization. In addition, we studied the properties of the nitrogen-metabolizing enzymes of strain BI-42, including glutamine synthetase (GS), glutamate dehydrogenase (GDH), and glutamate synthase (GOGAT), in order to characterize the glutamate auxotrophy of this organism.

\section{MATERIALS AND METHODS}

Chemicals. All of the chemicals used were analytical grade and were purchased from Sigma Chemical Co., St. Louis, Mo., E. Merck, Darmstadt, Germany, and SRL Pvt., Ltd., Bombay, India. Yeast extract, tryptone and agar-agar were obtained from Difco Laboratories, Detroit, Mich., and Dowex-1-chloride (50-100 dry mesh) was obtained from Aldrich Chemical, Inc. $\mathrm{NaH}^{14} \mathrm{CO}_{3}$ was purchased from Bhabha Atomic Research Centre, Trombay, India.

Enrichment and isolation. Soil samples were collected from different agricultural fields around Calcutta, India. The soil samples $(25 \mathrm{~g})$ were moistened with $5 \mathrm{ml}$ of sterile distilled water and enriched by adding sodium thiosulfate (100 $\mathrm{mg}$ ), sodium sulfite $(50 \mathrm{mg})$, or elemental sulfur $(25 \mathrm{mg})$. After thorough mixing, the preparations were incubated in petri dishes at $30^{\circ} \mathrm{C}$ for 10 days. Further enrichment was carried out in mineral salts broth $(\mathrm{pH} 8.0)$ supplemented with phenol red $(0.02 \mathrm{~g} /$ liter $)$ and either $\mathrm{Na}_{2} \mathrm{~S}_{2} \mathrm{O}_{3} \cdot 5 \mathrm{H}_{2} \mathrm{O}(5 \mathrm{~g} / \mathrm{liter})$ or thiosulfate plus yeast extract $(5 \mathrm{~g} / \mathrm{liter})$. Portions $(1 \mathrm{~g})$ of the enriched soil samples were transferred into $250-\mathrm{ml}$ conical flasks containing $50 \mathrm{ml}$ of enrichment medium, and the resulting preparations were incubated in a gyratory water bath shaker (model $\mathrm{G} 76$; New Brunswick) at $220 \mathrm{rpm}$ and $30^{\circ} \mathrm{C}$. After 2 days of incubation, one flask turned yellow, indicating that acid was formed. Serial dilutions of the contents of this flask were plated onto mineral salts-thiosulfate agar and onto mineral saltsthiosulfate-yeast extract agar. After 4 days of incubation at $30^{\circ} \mathrm{C}$, a few colonies with yellow halos appeared on the mineral salts-thiosulfate-yeast extract agar plates. These colonies were purified by repeated streaking on the same medium. Thus, a purified culture was obtained, and this culture was designated strain BI-42.

Medium and growth conditions. The mineral salts medium contained (per liter) $4.0 \mathrm{~g}$ of $\mathrm{Na}_{2} \mathrm{HPO}_{4}, 1.5 \mathrm{~g}$ of $\mathrm{KH}_{2} \mathrm{PO}_{4}, 0.1 \mathrm{~g}$ of $\mathrm{MgCl}_{2} \cdot 5 \mathrm{H}_{2} \mathrm{O}, 1.0 \mathrm{~g}$ of 
$\mathrm{NH}_{4} \mathrm{Cl}$, and $2 \mathrm{ml}$ of a trace metal solution (53). The $\mathrm{pH}$ was adjusted to 8.0 with $4 \mathrm{~N} \mathrm{NaOH}$. Glutamate-yeast extract-mineral salt (GYM) medium contained (per liter) $4.0 \mathrm{~g}$ of $\mathrm{Na}_{2} \mathrm{HPO}_{4}, 1.5 \mathrm{~g}$ of $\mathrm{KH}_{2} \mathrm{PO}_{4}, 0.1 \mathrm{~g}$ of $\mathrm{MgCl}_{2} \cdot 5 \mathrm{H}_{2} \mathrm{O}, 0.5 \mathrm{~g}$ of sodium glutamate, and $0.1 \mathrm{~g}$ of yeast extract; the $\mathrm{pH}$ of this medium was 8.0 . GYM medium was used as the basic medium unless stated otherwise. Mixed-substrate medium was GYM medium supplemented with $\mathrm{Na}_{2} \mathrm{~S}_{2} \mathrm{O}_{3} \cdot 5 \mathrm{H}_{2} \mathrm{O}$ and an organic substrate. The media were sterilized by autoclaving them at $103 \mathrm{kPa}$ for $15 \mathrm{~min}$. For solid media $20.0 \mathrm{~g}$ of agar per liter was added.

The denitrifying activity of strain BI-42 was determined under microaerobic conditions by adding $\mathrm{KNO}_{3}(1.0 \mathrm{~g}$ /liter) to GYM medium containing organic substrates $(5 \mathrm{~g} /$ /iter $)$ or thiosulfate $(5 \mathrm{~g} /$ liter $)$ or both. Inverted Durham tubes were placed in the culture media to determine whether gas was formed. Whether anaerobic growth occurred, was determined with the BBL GasPak system (Becton Dickinson and Co., Cockeysville, Md.). Crossed-pool auxanography was performed as described by Holliday (10). All other routine biochemical tests and procedures were performed as described previously $(3,43)$.

Utilization of amino acids as sole nitrogen sources or sole nitrogen and carbon sources was determined in mineral salts medium lacking $\mathrm{NH}_{4} \mathrm{Cl}$. Utilization of organic compounds other than amino acids was determined in GYM medium containing substrates at concentrations of 1 to $5 \mathrm{~g} /$ liter

Utilization of inorganic sulfur compounds was determined in GYM medium containing various concentrations ( 0.1 to $10 \mathrm{~g} /$ liter) of different inorganic sulfur sources in addition to sodium succinate ( $5 \mathrm{~g}$ /liter). All of the sulfur compounds except elemental sulfur were sterilized by membrane filtration (pore size, 0.22 $\mu \mathrm{m}$; Millipore, Bangalore, India). Elemental sulfur was sterilized by intermittent steaming.

For the GS, GDH, and GOGAT assays cells were grown in GYM medium supplemented with sodium acetate $(10 \mathrm{~g} /$ /iter $) . \mathrm{NH}_{4} \mathrm{Cl}(1 \mathrm{~g} /$ /iter $)$ was added at the mid-log phase for induction, and the preparations were incubated for an additional $3 \mathrm{~h}$. Ribulose 1,5-bisphosphate (RuBP) carboxylase activity was assayed by using extracts of exponential-phase cells grown in GYM medium supplemented with thiosulfate or both thiosulfate and succinate.

Flagellum staining and electron microscopy. The presence of flagella was determined by using cells that were negatively stained with $2 \%$ phosphotungstic acid. Cells were placed onto a carbon-coated grid ( 300 mesh; diameter, $3 \mathrm{~mm}$ ) and examined with a JEOL model JEM $200 \mathrm{CX}$ electron microscope at an accelerating voltage of $80 \mathrm{kV}(36)$.

Susceptibility tests. Antibiotic resistance and the MICs of different antibiotics were determined on Luria agar. The MIC of an antibiotic was determined by comparing the number of colonies that appeared on antibiotic-containing plates with the number of colonies on control plates.

Extraction of respiratory lipoquinones and polar lipids. Respiratory lipoquinones and polar lipids were extracted from 100-mg portions of freeze-dried cultures by using the two-stage method described by Tindall $(47,48)$. Cells were stirred in a hexane-methanol $(1: 2, \mathrm{vol} / \mathrm{vol})$ solution, the preparation was placed on ice, and the respiratory lipoquinones were recovered in the hexane layer by adding 1 volume of cold hexane. The hexane phase was removed, and the respiratory lipoquinones were extracted a second time from the methanol phase by adding 2 volumes of hexane and 2 volumes of $0.3 \%$ aqueous $\mathrm{NaCl}$. The hexane phases were pooled and used for the lipoquinone analysis. Polar lipids were extracted by modifying the methanol- $0.3 \%$ aqueous $\mathrm{NaCl}$ phase so that a chloroform-methanol- $0.3 \% \mathrm{NaCl}$ ratio of $1: 2: 0.8(\mathrm{vol} / \mathrm{vol} / \mathrm{vol})$ was obtained. The extraction solvent was stirred, and the cell debris was removed by centrifugation. The polar lipids were recovered in the chloroform phase by modifying the preparation so that the chloroform-methanol- $0.3 \%$ aqueous $\mathrm{NaCl}$ ratio was $1: 1: 0.9$ (vol/ $/ \mathrm{vol} / \mathrm{vol})$.

Analysis of respiratory lipoquinones. The respiratory lipoquinones were separated into different classes (menaquinones and ubiquinones) by thin-layer chromatography on silica gel thin layers (catalog no. 805 023; Macherey-Nagel, Düren, Germany), using hexane-tertbutylmethylether $(9: 1, \mathrm{vol} / \mathrm{vol})$ as the solvent. UV-absorbing bands corresponding to menaquinones or ubiquinones were removed from the plate and analyzed by high-performance liquid chromatography (HPLC). The HPLC analysis was carried out with an LDC analytical HPLC (Thermoseparations, Darmstadt, Germany) equipped with a reverse-phase column ( 2 by $125 \mathrm{~mm} ; 3 \mu \mathrm{m}$; $\mathrm{RP}_{18}$; (Macherey-Nagel) by using methanol as the eluant. The respiratory lipoquinones were detected at $269 \mathrm{~nm}$.

Analysis of polar lipids. Polar lipids were separated by two-dimensional silica gel thin-layer chromatography (catalog no. 818 135; Macherey-Nagel). The eluant used for the first dimension was chloroform-methanol-water (65:25:4, vol/ $\mathrm{vol} / \mathrm{vol}$ ) and the eluant used for the second dimension was chloroform-methanolacetic acid-water $(80: 12: 15: 4, \mathrm{vol} / \mathrm{vol} / \mathrm{vol} / \mathrm{vol})$. Total lipids and specific functional groups were detected by using dodecmolybdo-phosphoric acid (total lipids) (17), zinzadze reagent (phosphate) (48), ninhydrin (free amino groups) (29), periodate-Schiff stain ( $\alpha$-glycols) (37), dragendorff (quaternary nitrogen) (2), and anisaldehyde sulfuric acid (glycolipids) (21).

Fatty acid analysis. Fatty acids were analyzed as methyl ester derivatives prepared from $10 \mathrm{mg}$ of dry cell material. Cells were saponified and then transmethylated as described by Kuykendall et al. (20). Fatty acid methyl esters were analyzed by gas chromatography by using a nonpolar capillary column $(0.2 \mathrm{~mm}$ by $25 \mathrm{~m}$ ) and a flame ionization detector. The operating conditions were as follows: injection and detector temperature, $300^{\circ} \mathrm{C}$; inlet pressure, $60 \mathrm{kPa}$; split ratio, 100:1; injection volume, $2 \mathrm{ml}$; and temperature program, 170 to $270^{\circ} \mathrm{C}$, with the temperature increasing at a rate of $5^{\circ} \mathrm{C} / \mathrm{min}$.

Isolation and amplification of $16 \mathrm{~S}$ rDNA. Genomic DNA was extracted and 16S rDNA was amplified by the method of Rainey et al. (30). The PCR to amplify the 16S rDNA was performed by using primers $5^{\prime}$-GAGTTTGATCCT GGCTCAG-3' (forward primer) and 5'-AGAAAGGAGGTGATCCAGCC-3' (reverse primer) as described by Stackebrandt and Charfreitag (40). The PCR products were sequenced directly by using a Taq DyeDeoxy terminator cycle sequencing kit (Applied Biosystems, Inc., Foster City, Calif.) and a model 373A DNA sequencer (Applied Biosystems).

$16 \mathrm{~S}$ rDNA sequence analysis. The $16 \mathrm{~S}$ rDNA sequence which we determined was manually aligned with previously published sequences obtained from the Ribosomal Database Project for members of the actinomycete line of descent as described by Maidak et al. (24). Pairwise evolutionary distances were computed by using the corrections of Jukes and Cantor (12). A more detailed analysis was carried out with the organisms which were found to be most closely related to BI-42. Trees were reconstructed as described by De Soete (5).

Preparation of extract. The cell extract used for enzyme assays was prepared by harvesting cells at the mid-exponential phase and then washing and resuspending the resulting cell pellet in $10 \mathrm{mM} \mathrm{KPO}_{4}$ buffer $(\mathrm{pH} 7.0)$ containing $1 \mathrm{mM}$ EDTA (disodium salt) and $7 \mathrm{mM} 2$-mercaptoethanol for the GDH and GOGAT assays and in $100 \mathrm{mM}$ Tris-HCl buffer (pH 8.2) containing $20 \mathrm{mM} \mathrm{MgCl}_{2}, 5 \mathrm{mM}$ $\mathrm{NaHCO}_{3}$, and $0.5 \mathrm{mM}$ dithiothreitol for the RuBP carboxylase assay. The cells were sonicated with a Braunsonic 1510 sonicator six times $(30 \mathrm{~s} \mathrm{each})$ at $150 \mathrm{~W}$ in an ice bath. The cell debris was removed by centrifugation at $28,000 \times \mathrm{g}$ for $30 \mathrm{~min}$, and the supernatant was used as the enzyme source. For the GS assay, $10 \mathrm{ml}$ of exponentially growing cells was treated with cetyltrimethylammonium bromide $(0.1 \mathrm{~g} / \mathrm{liter})$ and then shaken thoroughly for $3 \mathrm{~min}$. The treated cultures were chilled immediately and centrifuged at $4^{\circ} \mathrm{C}$, and the resulting preparations were washed and resuspended in $1 \mathrm{ml}$ of an ice-cold $\mathrm{KCl}$ solution (10 g/liter). These cell suspensions were used for the GS activity assay.

Enzyme assays. GDH activity was measured by the method of Maulick and Ghosh (26). The 1-ml reaction mixture used for the NADPH-dependent assay contained $50 \mathrm{mM}$ Tris- $\mathrm{HCl}$ buffer ( $\mathrm{pH} 8.5$ ), $50 \mathrm{mM} \mathrm{NH}_{4} \mathrm{Cl}, 1 \mathrm{mM}$ 2-oxoglutarate, $0.1 \mathrm{mM} \mathrm{NADPH}$, and the cell extract. The assay was performed at $30^{\circ} \mathrm{C}$ by measuring the rate of oxidation of NADPH at $340 \mathrm{~nm}$ with a Shimadzu UVvisible recording spectrophotometer (model UV 240). Similarly, the NADHdependent GDH activity was measured by replacing NADPH with $1 \mathrm{mM}$ NADH and increasing the concentration of 2-oxoglutarate to $10 \mathrm{mM}$. After incubation for $3 \mathrm{~min}$ at $30^{\circ} \mathrm{C}$, the reaction was stopped by adding $6.5 \mathrm{ml}$ of $100 \mathrm{mM} \mathrm{NaOH}$, and the $A_{340}$ was determined. The oxidative deamination of glutamate by GDH was assayed by measuring the formation of NADPH at $340 \mathrm{~nm}$ by using an assay mixture containing $100 \mathrm{mM}$ Tris- $\mathrm{HCl}(\mathrm{pH} 8.8), 25 \mathrm{mM}$ glutamate, and $0.5 \mathrm{mM}$ NADP in a final volume of $1 \mathrm{ml}$.

GOGAT activity was measured by using 2-ketoglutarate and determining glutamine-dependent oxidation of NADPH as described by Meers et al. (27). GS activity was measured by the $\tau$-glutamyl transferase method described by Miller et al. (28). In every case, the $\tau$-glutamyl transferase activities in the presence and absence of $60 \mathrm{mM} \mathrm{MgCl}$ were measured to determine the active state of the enzyme. The reaction mixture was incubated for $10 \mathrm{~min}$ at $30^{\circ} \mathrm{C}$, and the amount of $\tau$-glutamyl hydroxymate formed was determined at $535 \mathrm{~nm}$ by using a reagent blank for comparison. Specific activity was expressed as the amount of enzyme which catalyzed the formation or disappearance of $1 \mu \mathrm{mol}$ of product or substrate per min.

The RuBP carboxylase activity in the cell extract was determined as described by Kelly et al. (16). The final volume of the assay mixture, which contained cell extract ( 0.1 to $0.4 \mathrm{~g}$ of protein), was $0.3 \mathrm{ml}$. The reaction was initiated with RuBP and was terminated after $0.5,1,1.5,2,3$, and $4 \mathrm{~min}$ by adding $0.2 \mathrm{ml}$ of acetic acid. Zero-time and RuBP-free controls were included. Each reaction mixture was dried in its vial, $5 \mathrm{ml}$ of scintillation fluid, which contained $10 \mathrm{~g}$ of 2,5-diphenyloxazole per liter, $0.25 \mathrm{~g}$ of 1,4-bis(5-phenyl-2-oxazolyl)benzene (POPOP) per liter, and $100 \mathrm{~g}$ of naphthalene per liter in 1,4-dioxane, was added, and ${ }^{14} \mathrm{CO}_{2}$ incorporation was determined with a Beckman scintillation counter.

Analytical methods. DNA base composition was determined by the thermal denaturation method of Marmur and Doty (25). The growth of cells was monitored by measuring optical density at $660 \mathrm{~nm}$. Protein contents were estimated by using the method of Lowry et al. (22) and bovine serum albumin as the standard. The concentrations of thiosulfate and tetrathionate in culture filtrates were determined as described by Kelly et al. (15). The sulfite content was determined by the method of Truper and Schlegel (49), as modified by Suzuki and Silver (45). The sulfate content was determined by the method of Berglund and Sorbo (1) and by the method of Gleen and Quastel (7); since a concentration of thiosulfate greater than $2.0 \mu \mathrm{mol} / 5 \mathrm{ml}$ of reaction mixture interfered with the sulfate determination when the first method was used, the second method was always used to confirm the results.

Nucleotide sequence accession number. The $16 \mathrm{~S}$ rDNA sequence of strain BI- 42 has been deposited in the EMBL data library under accession number X81044. 


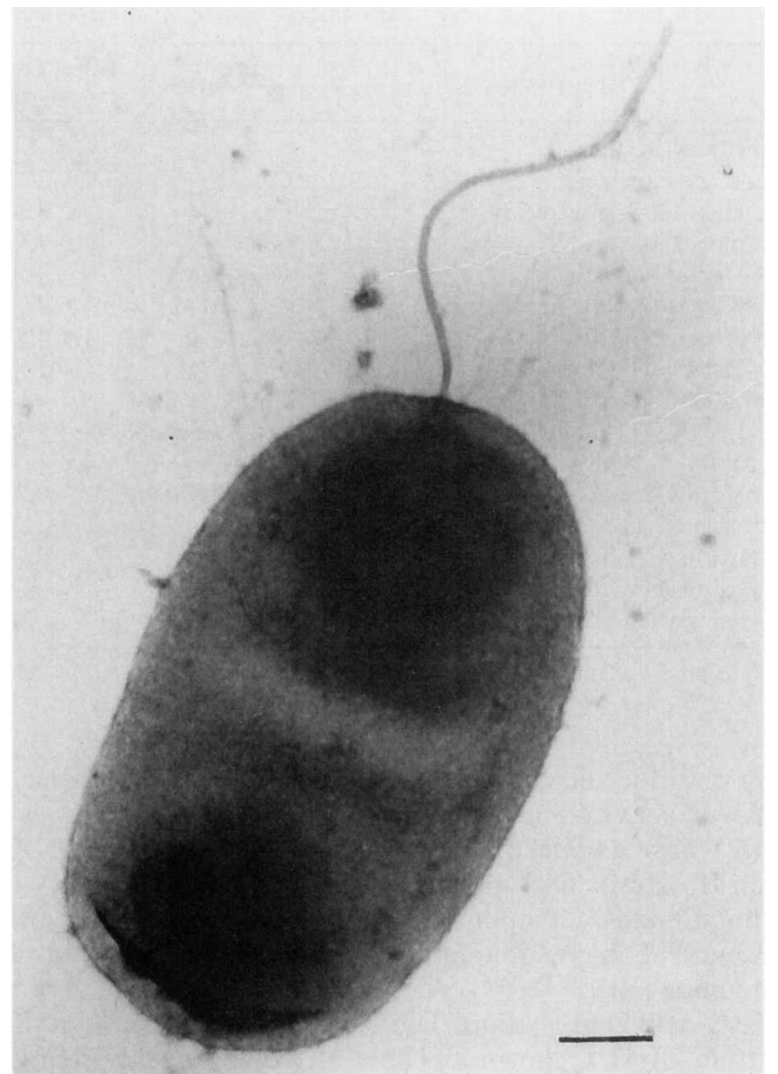

FIG. 1. Electron micrograph of a strain BI-42 cell, showing the single polar flagellum. Bar $=200 \mathrm{~nm}$.

\section{RESULTS}

Morphological and biochemical features of strain BI-42. Colonies of the organism which we isolated grown on Luria agar or on thiosulfate-yeast extract agar were circular, 1 to 1.5 $\mathrm{mm}$ in diameter, smooth, mucoid, round, and creamy colored. Single colonies appeared within 4 days at $30^{\circ} \mathrm{C}$. The cells stained gram negative and were motile, rod shaped, $0.85 \mu \mathrm{m}$ wide, and 1.4 to $1.6 \mu \mathrm{m}$ long. The cells occurred mostly singly, did not form spores, and were motile by means of a single polar flagellum (Fig. 1). Cells grown on GYM medium containing thiosulfate and yeast extract or on mixed-substrate agar containing thiosulfate and succinate did not form sulfur deposits on the colony surfaces. The isolate which we obtained was designated $\mathrm{BI}-42$.

Strain BI-42 was not able to grow without small amounts of yeast extract when sugars, amino acids, and tricarboxylic acid cycle intermediates were used as the sole sources of carbon and energy. Crossed-pool auxanography revealed that nicotinic acid $(0.001 \mathrm{~g} /$ liter $)$ partially replaced the requirement for $0.1 \mathrm{~g}$ of yeast extract per liter. Strain BI-42 also was not able to grow in a chemically defined medium containing the inorganic nitrogen compounds $\mathrm{NH}_{4} \mathrm{Cl}, \mathrm{KNO}_{3}$, and $\left(\mathrm{NH}_{4}\right)_{2} \mathrm{SO}_{4}$ as sole nitrogen sources. Growth was observed when these nitrogen compounds were replaced by glutamate $(0.5 \mathrm{~g} / \mathrm{liter})$. These observations led to the formulation of GYM medium.

Strain BI-42 did not grow anaerobically in the presence or absence of nitrate with any of the substrates tested. However, under microaerobic conditions, strain BI-42 formed gas in GYM medium containing malate, succinate, glucose, or sucrose. When thiosulfate was added to the media, gas was not produced. The gas produced was not absorbed by $\mathrm{NaOH}$. Thus, the gas was identified as $\mathrm{N}_{2}$ or $\mathrm{N}_{2} \mathrm{O}$, the products of denitrification. Strain BI-42 exhibited catalase, oxidase, and nitrate reductase activities and could grow on Simmons citrate agar and MacConkey agar. Methyl red, urease, starch hydrolysis, indole production, $\mathrm{H}_{2} \mathrm{~S}$ production, Voges-Proskaeur, gelatin hydrolysis, and pigment production tests were negative. The optimum temperature for growth was 30 to $32^{\circ} \mathrm{C}$. The $\mathrm{pH}$ range for growth was 6.0 to 9.0 , and the optimum $\mathrm{pH}$ was 7.5 to 8.0 .

Utilization of organic compounds. Glutamate, glutamine, proline, cysteine, aspartic acid, serine, asparagine, alanine, and lysine were used as both nitrogen and carbon sources, while arginine and histidine were used as nitrogen sources. In contrast, leucine, glycine, isoleucine, methionine, tyrosine, tryptophan, and phenylalanine did not support growth.

Strain BI-42 grew heterotrophically in GYM medium supplemented with glucose, fructose, rhamnose, xylose, sorbose, ribose, galactose, citrate, gluconate, acetate, pyruvate, arabinose, succinate, and malate. Glycerol, raffinose, mannitol, formate, lactate, glyoxylate, propionate, salicylate, butyrate, cyclohexanol, $p$-aminobenzoate, and methanol did not support the growth of this organism.

Growth and oxidation of sulfur compounds. In GYM medium supplemented with thiosulfate the growth yield of strain BI-42 was almost the same as the growth yield in GYM medium alone. No stimulation of growth occurred, although a considerable amount of thiosulfate was consumed (data not shown). However, marked stimulation of growth was observed when GYM medium was supplemented with sodium succinate in addition to thiosulfate. The growth yield varied with the concentration of thiosulfate (Fig. 2); the greatest growth $\left(A_{660}\right.$, 1.2 to 1.3 ) was observed at a concentration of $5 \mathrm{~g} /$ liter. Under these conditions, conversion of thiosulfate to sulfate was stoichiometric, and the $\mathrm{pH}$ of the medium decreased from 8.0 to 6.6 (Fig. 3). Thiosulfate added to the medium was almost

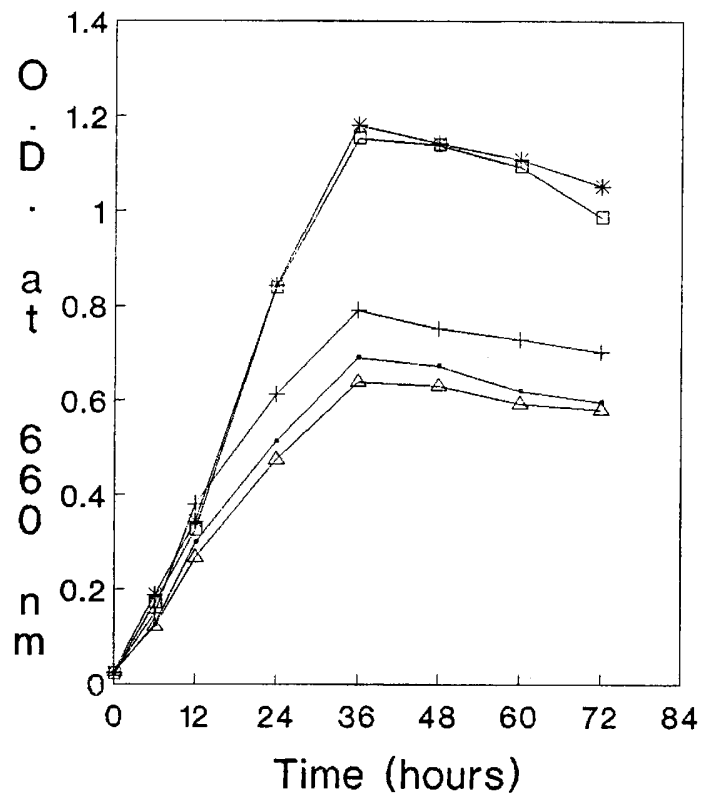

FIG. 2. Effect of thiosulfate on the growth response of strain BI-42 in GYM medium containing succinate. Symbols: ., $0.1 \mathrm{~g}$ of thiosulfate per liter;,$+ 1.0 \mathrm{~g}$ of thiosulfate per liter; *, $5.0 \mathrm{~g}$ of thiosulfate per liter; $\square, 10.0 \mathrm{~g}$ of thiosulfate per liter; $\triangle$, medium containing only sodiam succinate $(5.0 \mathrm{~g} /$ liter $)$. O.D., optical density. 


\section{Sulfur compounds ( $\mu \mathrm{g}$ atoms of $S / \mathrm{ml})$}

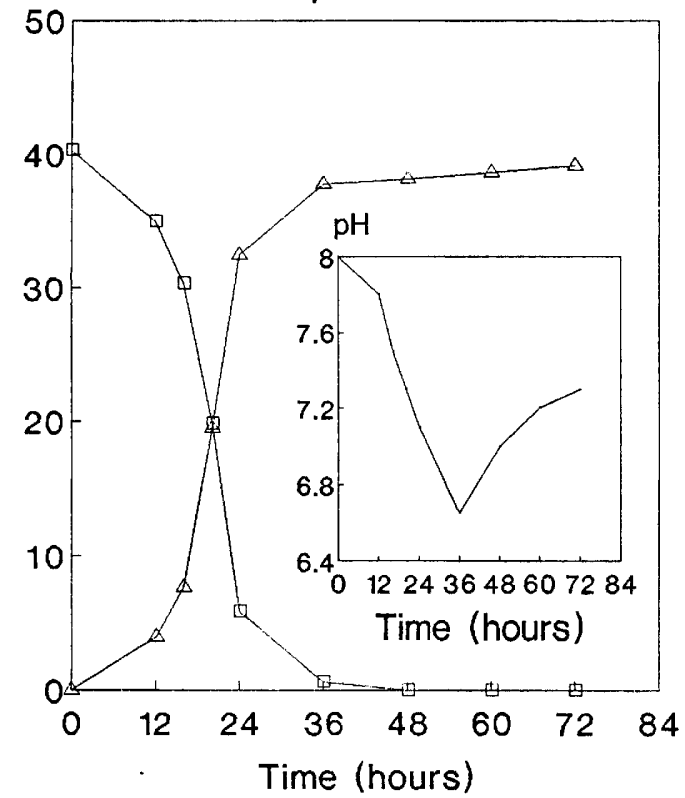

FIG. 3. Time course of utilization of thiosulfate $(\square)$, release of sulfate $(\triangle)$ and change in $\mathrm{pH}$ (inset) during growth of strain BI-42 in GYM medium containing thiosulfate $(5.0 \mathrm{~g} / \mathrm{liter})$ and sodium succinate $(5.0 \mathrm{~g} / \mathrm{liter})$

entirely consumed within $36 \mathrm{~h}$. Interestingly, the $\mathrm{pH}$ of the medium increased after 36 to $40 \mathrm{~h}$ of growth. Like thiosulfate, tetrathionate also stimulated growth in the presence of succinate, but $\mathrm{NaSCN}, \mathrm{Na}_{2} \mathrm{SO}_{3}$, and $\mathrm{Na}_{2} \mathrm{SO}_{4}$ inhibited growth (data not shown).

$\mathrm{CO}_{2}$ fixation. No RuBP carboxylase activity was detected in strain BI-42.

Susceptibility to antibiotics. The MICs of several antibiotics for strain BI-42 were determined. Growth of this organism was inhibited by $120 \mu \mathrm{g}$ of streptomycin per $\mathrm{ml}, 10 \mu \mathrm{g}$ of tetracycline per $\mathrm{ml}, 40 \mu \mathrm{g}$ of neomycin per $\mathrm{ml}, 20 \mu \mathrm{g}$ of chloramphenicol per $\mathrm{ml}$, and $15 \mu \mathrm{g}$ of rifampin, per $\mathrm{ml}$. Even ampicillin did not inhibit growth even at a concentration of $200 \mu \mathrm{g} / \mathrm{ml}$.

GS, GDH, and GOGAT activities. Strain BI- 42 cells contained readily detectable levels of GS and GDH (Table 1). Addition of $\mathrm{NH}_{4} \mathrm{Cl}$ in the exponential phase of growth reduced the GS activity. The GS activity measured in the presence of $\mathrm{Mn}^{2+}$ alone was significantly higher than the GS activity measured in the presence of both $\mathrm{Mn}^{2+}$ and $\mathrm{Mg}^{2+}$. NADP ${ }^{+}-$and NADH-dependent GDH activities were not detected. However, considerable activity in the assimilatory direction was observed when NADPH was the cofactor. Addition of ammo-

TABLE 1. Effect of $\mathrm{NH}_{4}{ }^{+}$on GS, GDH, and GOGAT activities of strain BI-42

\begin{tabular}{lcccc}
\hline \multirow{2}{*}{$\begin{array}{c}\text { Addition to } \\
\text { medium }\end{array}$} & \multicolumn{3}{c}{ Sp act (nmol/min/mg of protein) } \\
\cline { 2 - 3 } & $\mathrm{Mn}^{2+}$ & $\mathrm{Mn}^{2+}+\mathrm{Mg}^{2+}$ & GDH & GOGAT \\
\hline None & 1,347 & 422 & 22 & $<0.1$ \\
$\mathrm{NH}_{4}{ }^{+a}$ & 827 & 160 & 18 & $<0.1$ \\
\hline
\end{tabular}

${ }^{a} \mathrm{NH}_{4}{ }^{+}$was added to a concentration of $0.1 \%$ during the exponential phase of growth. The preparation was incubated for $3 \mathrm{~h}$, and then the enzyme activities were determined.
TABLE 2. Cellular fatty acid composition of strain BI-42

\begin{tabular}{|c|c|c|}
\hline Fatty acid & Designation & $\begin{array}{c}\% \text { in strain } \\
\text { BI- } 42^{a}\end{array}$ \\
\hline \multicolumn{3}{|l|}{ Nonhydroxylated acids } \\
\hline Pentadecanoic acid & $C_{15: 0}$ & 2.33 \\
\hline cis-Hexadec-9-enoic acid & $C_{16: 1} \omega 7 \mathrm{c}$ & 3.70 \\
\hline Hexadecanoic acid & $\mathrm{C}_{16: 0}$ & 7.58 \\
\hline cis-Hepta-9-enoic acid & $\mathrm{C}_{17: 1} \omega 8 \mathrm{c}$ & 3.56 \\
\hline cis-9,10-Methylene hexadecanoic acid & $\mathrm{C}_{17: 0}$ cyclo & 2.08 \\
\hline Heptadecanoic acid & $\mathrm{C}_{17: 0}$ & 4.82 \\
\hline cis-Octadec-9-enoic acid & $\mathrm{C}_{18: 1} \omega 7 \mathrm{c}$ & 61.55 \\
\hline Octadecanoic acid & $\mathrm{C}_{18: 0}$ & 0.67 \\
\hline $\begin{array}{l}\text { cis-Cyclo-10,11-methylene octadecanoic } \\
\text { acid }\end{array}$ & $\mathrm{C}_{19: 0}$ cyclo $\omega 8 \mathrm{c}$ & 8.35 \\
\hline 10-Methyl octadecanoic acid & $\mathrm{C}_{19: 0}$ 10-methyl & 0.71 \\
\hline \multicolumn{3}{|l|}{ Hydroxylated acid } \\
\hline 3-Hydroxypentadecanoic acid & $\mathrm{C}_{15: 0} 3-\mathrm{OH}$ & 0.49 \\
\hline 3-Hydroxyhexadecanoic acid & $\mathrm{C}_{16: 0} 3-\mathrm{OH}$ & 3.25 \\
\hline 3-Hydroxyheptadecanoic acid & $\mathrm{C}_{17: 0} 3-\mathrm{OH}$ & 0.90 \\
\hline
\end{tabular}

${ }^{a}$ Percentages of the total fatty acids.

nium chloride did not influence the GDH activity (Table 1 ). GOGAT activity was not observed in this organism.

DNA base composition. The $\mathrm{G}+\mathrm{C}$ content of the DNA of strain BI-42 was $68.2 \mathrm{~mol} \%$.

Ubiquinones. Ubiquinone was the sole respiratory quinone present. The major ubiquinone contained 10 isoprenoid units (ubiquinone 10).

Fatty acid composition. The cellular fatty acid composition of strain BI-42 is shown in Table 2 . The fatty acids identified were the saturated straight-chain acids $\mathrm{C}_{15: 0}, \mathrm{C}_{16: 0}, \mathrm{C}_{17: 0}, \mathrm{C}_{18: 0}$, and $\mathrm{C}_{19: 0}$ 10-methyl; the unsaturated straight-chain acids $\mathrm{C}_{16: 1}$ $\omega 7 \mathrm{c}, \mathrm{C}_{17: 1} \omega 8 \mathrm{c}$, and $\mathrm{C}_{18: 1} \omega 7 \mathrm{c}$; and the nonhydroxy acids $\mathrm{C}_{17: 1}$ cyclopropane and $\mathrm{C}_{19: 1} \omega 8 \mathrm{c}$. cis-Octadec-9-enoic acid $\left(\mathrm{C}_{18: 1}\right.$ $\omega 7 \mathrm{c})$ was the predominant compound among the other nonhydroxy acids. The major hydroxylated fatty acids found were $\mathrm{C}_{15: 0} 3-\mathrm{OH}, \mathrm{C}_{16: 0} 3-\mathrm{OH}$ and $\mathrm{C}_{17: 0} 3-\mathrm{OH}$.

Polar lipids. The polar head groups consisted of phosphatidylglycerol, phosphatidylethanolamine, phosphatidylcholine, diphosphatidylglycerol, and an unidentified amino lipid.

16S rDNA sequencing and phylogenetic analysis. A total of 1,377 nucleotides of the $16 \mathrm{~S}$ rDNA were sequenced. The $16 \mathrm{~S}$ rDNA sequence of strain BI-42 was most similar to the sequence of Beijerinckia indica (level of similarity, 92.8\%) and to the sequences of Rhodopseudomonas palustris, Nitrobacter winogradskyi, Blastobacter denitrificans, and Bradyrhizobium japonicum (levels of similarity, 92.0 to $92.5 \%$ ), which are members of the alpha subclass of the Proteobacteria. The distance matrix phylogenetic tree based on levels of difference between strain BI-42 and 19 reference strains that belong to the alpha subclass of the Proteobacteria indicated that strain BI-42 belongs to a new lineage located between the methylotrophs, the genus Beijerinckia, and the Rhodopseudomonas palustris group (Fig. 4). No close relationship was found between strain BI-42 and other sulfur-oxidizing bacteria, such as Thiobacillus acidophilus and Acidiphilium species (levels of 16S rDNA similarity, $<88 \%$ ).

\section{DISCUSSION}

A great deal of work has been performed to increase our understanding of the oxidation of inorganic sulfur compounds by obligately or facultatively chemolithotrophic bacteria, especially bacteria belonging to the genus Thiobacillus (44). These bacteria oxidize inorganic sulfur compounds under autotrophic 


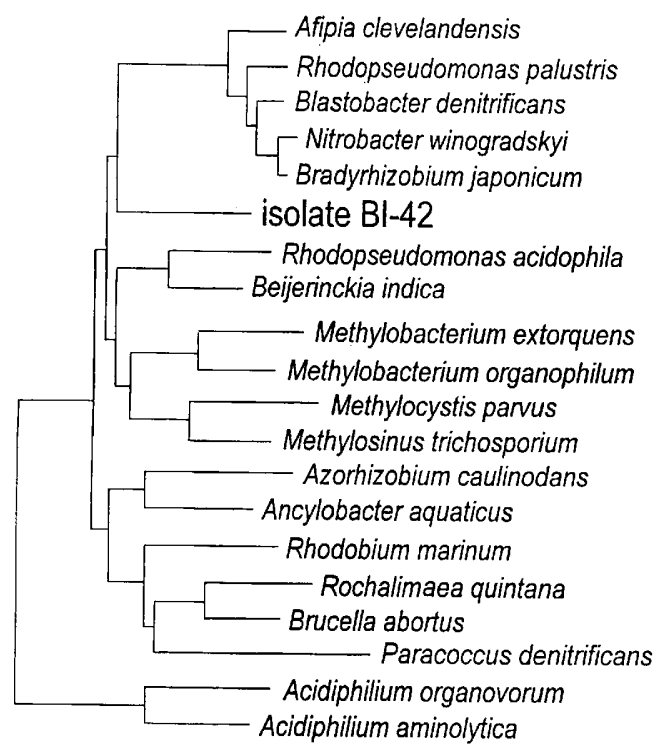

$5 \%$

FIG. 4. Phylogenetic tree based on dissimilarity values, showing the relationships between strain BI-42 and related reference organisms. Bar $=5 \%$ nucleotide difference.

or mixotrophic growth conditions (19). However, it has also been reported that Thiobacillus sp. strain Q (8) and C. thiocyclus (39) oxidize sulfur compounds to yield metabolically useful energy under lithoheterotrophic growth conditions. In this context, the stimulation of strain BI-42 growth by thiosulfate observed in an organic culture medium is very similar to the chemolithoheterotrophic growth of Thiobacillus sp. strain Q described by Gommers and Kuenen (8).

The following major physiological characteristics of strain BI-42 distinguish it from similar gram-negative bacteria, including Thiobacillus novellus (13), Thiobacillus versutus (46), Thiobacillus sp. strain Q (8), Thiosphaera pantotropha (32), Pseudomonas aeruginosa (35), Achromobacter stutzeri (41), and Pseudomonas sp. strain 16B (50), which are capable of oxidizing inorganic sulfur compounds: (i) strain BI-42 cannot grow in chemically defined medium containing ammonia or nitrate as the sole nitrogen source; (ii) strain $\mathrm{BI}-42$ requires trace amounts of yeast extract as a growth factor; and (iii) strain $\mathrm{BI}-42$ is auxotrophic for glutamate.

A large number of organic compounds supported heterotrophic growth of strain BI-42 but this organism was not able to utilize aromatic compounds and alcohol. Unlike Thiobacillus sp. strain Q (8), strain BI-42 grown on mixed-substrate agar did not produce sulfur deposits on the colony surfaces. Even though both strain BI-42 and Thiobacillus versutus (46) denitrify under heterotrophic growth conditions, the absence of denitrification under mixed-substrate growth conditions differentiates strain BI-42 from Thiosphaera pantotropha and Thiobacillus versutus (32). This may be due to the inhibitory effect of thiosulfate for denitrifying activity under mixed-substrate growth conditions.

Despite the presence of an assimilatory GDH, strain BI-42 was not able to grow in culture medium containing ammonia as the sole nitrogen source. Thus, the assimilatory GDH may not have been sufficient for assimilation of ammonia.

The fatty acid composition of BI-42 was distinct from the fatty acid compositions of other autotrophic and facultatively chemolithoautotrophic sulfur oxidizers (14). The uniqueness of this isolate was supported by the presence of hydroxy fatty acids along with 10-methyl and cyclic fatty acids, which are not found in any other species belonging to the alpha subclass of the class Proteobacteria (4, 23, 33).

The respiratory quinone present in strain BI-42 was a ubiquinone with 10 isoprenoid units (ubiquinone 10), which indicates that this organism is closely related to members of the alpha subclass of the Proteobacteria. The lipids of the polar head groups of strain BI-42 were not unique but were similar to those found in the obligate or restricted facultative methylotrophs (11). The presence of ubiquinone 10 and phosphatidylcholine and the high level of the unsaturated nonhydroxy fatty acid $\mathrm{C}_{18: 1} \omega 7 \mathrm{C}$ resembles characteristics of the genus Methylobacterium $(9,11)$.

Oxidation of thiosulfate in GYM medium was gratuitous since it did not increase the growth yield. Despite thiosulfate oxidation, the low cell yield clearly indicated that like other chemolithoheterotrophic sulfur oxidizers, strain BI-42 could not assimilate carbon dioxide $(8,31)$. The failure to detect RuBP carboxylase is consistant with this conclusion. In contrast, the increased growth yield obtained with thiosulfate and succinate implies that thiosulfate oxidation is used to enhance heterotrophic carbon assimilation. Under these growth conditions, the stoichiometry for thiosulfate oxidation to sulfate by strain BI-42 is very similar to the stoichiometry reported for Thiobacillus thioparus (52) and Thiobacillus novellus (34).

As determined by a $16 \mathrm{~S}$ rDNA sequence analysis, biochemical tests, and a chemical composition analysis, strain BI-42 represents a novel genus and species in the alpha subclass of the Proteobacteria, for which the name Bosea thiooxidans is proposed.

Description of Bosea gen. nov. Bosea (Bos' e.a. M. L. gen. n. Bosea, of J. C. Bose the founder of the Bose Institute, where the organism was isolated). Cells are gram-negative rods that occur mostly as single cells. Strictly aerobic. The optimum temperature for growth is 30 to $32^{\circ} \mathrm{C}$. No growth occurs at temperatures below $20^{\circ} \mathrm{C}$ and above $37^{\circ} \mathrm{C}$. Oxidase and catalase positive. Reduced inorganic sulfur is oxidized in the presence of organic carbon sources. No autotrophic growth occurs.

Phosphatidylglycerol, phosphatidylethanolamine, phosphatidylcholine, diphosphatidylglycerol, and an amino lipid are the major lipid constituents of the polar head groups. The abundant fatty acids are cis-octadec-9-enoic acid $\left(\mathrm{C}_{18: 1} \omega 7 \mathrm{c}\right)$, ciscyclo-10,11-methylene octadecanoic acid $\left(\mathrm{C}_{19: 0}\right.$ cyclo $\left.\omega 8 \mathrm{c}\right)$, and hexadecanoic acid $\left(\mathrm{C}_{16: 0}\right)$. Hydroxylated fatty acids are also present. A $16 \mathrm{~S}$ rDNA sequence analysis of strain $\mathrm{BI}-42$ revealed that the genus branches intermediate to the genus Methylobacterium, the genus Beijerinckia, $R$. palustris, and related taxa. The type species is Bosea thiooxidans.

Description of Bosea thiooxidans sp. nov. Bosea thiooxidans (thi.o. ox'i. dans. Gr. n. thion, sulfur; M.L.v. oxido, make acid, oxidize; M.L. part. adj. thiooxidans, oxidizing sulfur). This bacterium was isolated from agricultural soil. Cells are straight rods that are $0.85 \mu \mathrm{m}$ wide by 1.4 to $1.6 \mu \mathrm{m}$ long. Cells occur singly. Motile by means of a single polar flagellum. Strictly aerobic. Spores are not formed. Colonies on agar containing thiosulfate and succinate or yeast extract are smooth, mucoid, round, and cream colored; these colonies are about 1 to 1.5 $\mathrm{mm}$ in diameter after 4 days of incubation. No sulfur deposition occurs on the colony surfaces. Glutamate, glutamine, and aspartate, but not $\mathrm{NH}_{4}{ }^{+}, \mathrm{NO}_{3}{ }^{-}$, and urea, can serve as nitrogen sources. This organism can denitrify and produce gas only in heterotrophic growth medium containing nitrate. It has glutamate auxotrophy and requires yeast extract $(0.1 \mathrm{~g} /$ liter $)$ as a 
growth factor. The pH range for growth is 6.0 to 9.0 , and the optimum $\mathrm{pH}$ is 7.5 to 8.0 .

A variety of organic compounds support heterotrophic growth in GYM medium. These compounds include glucose, fructose, rhamnose, xylose, sorbose, ribose, arabinose, galactose, citrate, gluconate, succinate, malate, acetate, glutamate, glutamine, proline, cysteine, aspartic acid, serine, asparagine, alanine, lysine, common hexoses, pentoses, and organic acids, pyruvate, and some amino acids.

This species is a chemolithoheterotroph. Thiosulfate stimulates growth in the presence of succinate. Tetrathionate is oxidized slowly. Sulfite, thiocyanate, and elemental sulfur do not support growth.

The $\mathrm{G}+\mathrm{C}$ content is $68.2 \mathrm{~mol} \%$. Ubiquinone 10 is the major ubiquinone. A culture of the type strain has been deposited in the Deutsche Sammlung von Mikroorganismen und Zellkulturen as strain DSM 9653.

\section{ACKNOWLEDGMENTS}

We are indebted to Sudhamoy Ghosh of the Department of Biochemistry, Bose Institute, Calcutta, India, for his helpful suggestions. We thank H. G. Truper of the Institut fur Mikrobiologie, Universitat Bonn, Bonn, Germany, for help with the nomenclature.

This work was supported by an individual fellowship from Bose Institute to S.K.D.

\section{REFERENCES}

1. Berglund, F., and B. H. Sorbo. 1960. Turbidimetric analysis of inorganic sulfate in serum, plasma and urine. Scand. J. Clin. Lab. Invest. 12:147-150.

2. Bregoff, H. M., E. E. Roberts, and C. C. Delwiche. 1953. Paper chromatog raphy of quaternary ammonium bases and related compounds. J. Biol. Chem. 205:565-574.

3. Cruickshank, R., J. P. Duguid, B. P. Marmion, and R. H. A. Swain. 1975 The practice of medical microbiology, 12th ed., vol. 2. Longman Group, Ltd., Churchill Livingstone, New York.

4. Das, P. K., M. Basu, and G. C. Chatterjee. 1979. Lipid profile of the strains of Agrobacterium tumefaciens in relation to agrocin resistance. J. Gen. Appl. Microbiol. 25:1-9.

5. De Soete, G. 1983. A least squares algorithm for fitting additive trees to proximity data. Psychometrika 48:621-626.

6. Friedrich, C. G., and G. Mitrenga. 1981. Oxidation of thiosulfate by Paracoccus denitrificans and other hydrogen bacteria. FEMS Microbiol. Lett. 10:209-212.

7. Gleen, H., and J. H. Quastel. 1952. Sulfur metabolism in soil. Appl. Microbiol. 1:70-77.

8. Gommers, P. J. F., and J. G. Kuenen. 1988. Thiobacillus strain Q, a chemolithoheterotrophic sulfur bacterium. Arch. Microbiol. 150:117-125.

9. Green, P. N., and I. J. Bousfield. 1982. A taxonomic study of some gramnegative facultatively methylotrophic bacteria. J. Gen. Microbiol. 128:623638

10. Holliday, R. 1956. A new method for identification of biochemical mutants of microorganisms. Nature (London) 178:987.

11. Jenkins, O., and D. Jones. 1987. Taxonomic studies on some gram negative methylotrophic bacteria. J. Gen. Microbiol. 133:453-473.

12. Jukes, T. H., and C. R. Cantor. 1969. Evolution of protein molecules, p 21-132. In H. N. Munro (ed.), Mammalian protein metabolism. Academic Press, New York.

13. Katayama-Fujimura, Y., and H. Kuraishi. 1980. Characterization of Thio bacillus novellus and its thiosulfate oxidation. J. Gen. Appl. Microbiol. 26: 357-367.

14. Katayama-Fujimura, Y., N. Tsuzaki, and H. Kuraishi. 1982. Ubiquinone, fatty acid and DNA base composition determination as a guide to the taxonomy of the genus Thiobacillus. J. Gen. Microbiol. 128:1599-1611.

15. Kelly, D. P., L. A. Chambers, and P. A. Trudinger. 1969. Cyanolysis and spectrophotometric estimation of trithionate in mixture with thiosulfate and tetrathionate. Anal. Chem. 41:898-901.

16. Kelly, D. P., A. P. Wood, J. C. Gottschal, and J. G. Kuenen. 1979. Autotrophic metabolism of formate by Thiobacillus strain $\mathrm{A}_{2}$. J. Gen. Microbiol. 114:1-13.

17. Kritchevsky, D., and M. C. Kirk. 1952. Detection of steroids in paper chromatography. Arch. Biochem. Biophys. 35:346-351.

18. Kuenen, J. G. 1989. The colourless sulfur bacteria, p. 1834-1837. In J. T Staley, M. P. Bryant, N. Pfennig, and J. G. Holt (ed.), Bergey's manual of systematic bacteriology, vol. 3. Williams and Wilkins, Baltimore.

19. Kuenen, J. G., and R. F. Beudeker. 1982. Microbiology of thiobacilli and other sulphur-oxidising autotrophs, mixotrophs and heterotrophs. Phil.
Trans. R. Soc. Lond. B Biol. Sci. 298:473-497.

20. Kuykendall, L. D., M. D. Roy, J. J. O Neill, and T. E. Devine. 1988. Fatty acids, antibiotic resistance and deoxyribonucleic acid homology groups of Bradyrhizobium japonicum. Int. J. Syst. Bacteriol. 38:358-361.

21. Lisboa, B. P. 1964 . Characterization of $\Delta^{4}-3$-oxo- $C_{21}$-steroids on thin-layer chromatograms by "in situ" colour reactions. J. Chromatogr. 16:136-151.

22. Lowry, O. H., N. J. Rosebrough, A. L. Farr, and R. J. Randall. 1951. Protein measurement with the Folin phenol reagent. J. Biol. Chem. 193:265275.

23. Mackenzie, S. L., M. S. Lapp, and J. J. Child. 1979. Fatty acid composition of Rhizobium spp. Can. J. Microbiol. 25:68-74.

24. Maidak, B. L., N. Larsen, M. A. McCaughey, R. Overbeek, G. J. Olsen, K. Fogel, J. Blandy, and C. R. Woese. 1994. The Ribosomal Database Project. Nucleic Acids Res. 22:3485-3487.

25. Marmur, J., and P. Doty. 1962. Determination of the base composition of deoxyribonucleic acid from its thermal denaturation temperature. J. Mol. Biol. 5:109-118.

26. Maulik, P., and S. Ghosh. 1986. NADPH/NADH-dependent cold-labile glutamate dehydrogenase in Azospirillum brasilense. Purification and properties. Eur. J. Biochem. 155:595-602.

27. Meers, J. L., D. W. Tempest, and C. M. Brown. 1970. Glutamine (amide): 2-oxoglutarate aminotransferase oxido reductase (NADP), an enzyme involved in the synthesis of glutamate by some bacteria. J. Gen. Microbiol. 64:187-194.

28. Miller, R. E., E. Shelton, and E. R. Stadtman. 1974. Zinc-induced paracrystalline aggregation of glutamine synthetase. Arch. Biochem. Biophys. 163: 155-171.

29. Patton, A. R., and P. Chism. 1951. Quantitative paper chromatography of amino acids: an evaluation of techniques. Anal. Chem. 23:1683-1689.

30. Rainey, F. A., M. Dorsch, H. W. Morgan, and E. Stackebrandt. 1992. 16S rDNA analysis of Spirochaeta thermophila: its phylogenetic position and implications for the systematics of the order Spirochaetales. Syst. Appl. Microbiol. 15:197-202.

31. Rittenberg, S. C. 1969. The role of exogenous organic matter in the physiology of chemolithotrophic bacteria. Adv. Microb. Physiol. 3:159-196.

32. Robertson, L. A., and J. G. Kuenen. 1983. Thiosphaera pantotropha gen. nov. sp. nov., a facultatively anaerobic, facultatively autotrophic sulfur bacterium. J. Gen. Microbiol. 129:2847-2855.

33. Romanovskaya, V. A., Y. R. Malashenko, and N. I. Grishchenko. 1980 Diagnosis of methane oxidizing bacteria by numerical methods based on the cellular fatty acid makeup. Mikrobiologiya 49:969-975.

34. Santer, M., J. Boyer, and U. Santer. 1959. Thiobacillus novellus. I. Growth on organic and inorganic media. J. Bacteriol. 78:197-202.

35. Schook, L. B., and R. S. Berk. 1978. Nutritional studies with Pseudomonas aeruginosa grown on inorganic sulfur sources. J. Bacteriol. 133:13771382 .

36. Sharma, D. P., C. Thomas, R. H. Hall, M. M. Levine, and S. R. Attridge. 1989. Significance of toxin-coregulated pili as protective antigens of Vibrio cholerae in the infant mouse model. Vaccine $7: 451-456$.

37. Shaw, N. 1968. The detection of lipids on thin-layer chromatograms with the periodate Schiff reagent. Biochim. Biophys. Acta 164:435-436.

38. Smith, A. J. 1966. The role of tetrathionate in the oxidation of thiosulfate by Chromatium sp. strain D. J. Gen. Microbiol. 42:371-380.

39. Sorokin, D. Y. 1992. Catenococcus thiocyclus gen. nov. sp. nov.-a new facultatively anaerobic bacterium from a near-shore sulphidic hydrothermal area. J. Gen. Microbiol. 138:2287-2292.

40. Stackebrandt, E., and O. Charfreitag. 1990. Partial 16S rRNA primary structure of five Actinomyces species: phylogenetic implications and development of an Actinomyces israelii-specific oligonucleotide probe. J. Gen. Microbiol. 136:37-43.

41. Starkey, R. L. 1934. The production of polythionates from thiosulfate by microorganisms. J. Bacteriol. 28:387-400.

42. Starkey, R. L. 1935. Isolation of some bacteria which oxidize thiosulfate. Soil Sci. 39:197-219.

43. Stolp, H., and D. Gadkari. 1981. Nonpathogenic members of the genus Pseudomonas, p. 719-741. In M. P. Starr, H. Stolp, H. G. Trüper, A. Balows, and H. G. Schlegel (ed.), The prokaryotes, vol. 1. Springer-Verlag, Berlin.

44. Suzuki, I. 1974. Mechanisms of inorganic oxidation and energy coupling. Annu. Rev. Microbiol. 28:85-101.

45. Suzuki, I., and M. Silver. 1965. The initial product and properties of the sulfur oxidizing enzyme of thiobacilli. Biochim. Biophys. Acta 122:2233.

46. Taylor, B. F, and D. S. Hoare. 1969. New facultative Thiobacillus and a reevaluation of the heterotrophic potential of Thiobacillus novellus. J. Bacteriol. 100:487-497.

47. Tindall, B. J. 1990. A comparative study of the lipid composition of Halobac terium saccharovorum from various sources. Syst. Appl. Microbiol. 13:128130.

48. Tindall, B. J. 1990. Lipid composition of Halobacterium lucusprofundi. FEMS Microbiol. Lett. 66:199-202.

49. Truper, H. G., and H. G. Schlegel. 1964. Sulfur metabolism in Thiorhodaceae. I. Quantitative measurements on growing cells of Chromatium 
okenii. Antonie van Leeuwenhoek 30:225-238.

50. Tuttle, J. H., P. E. Holmes, and H. W. Jannasch. 1974. Growth rate stimulation of marine pseudomonads by thiosulfate. Arch. Microbiol. 99:1-14.

51. Tuttle, J. H., and H. W. Jannasch. 1972. Occurrence and types of Thiobacillus-like bacteria in the sea. Limnol. Oceanogr. 17:532-543.

52. Vishniac, W. 1952. The metabolism of Thiobacillus thioparis. I. The oxidation of thiosulfate. J. Bacteriol. 64:363-373.
53. Vishniac, W., and M. Santer. 1957. The thiobacilli. Bacteriol. Rev. 21:195213.

54. Vitolins, M. I., and R. J. Swaby. 1969. Activity of sulfur-oxidizing microorganisms in some Australian soils. Austr. J. Soil Res. 7:171-183.

55. Widdel, F., and N. Pfenning. 1984. Dissimilatory sulfate- or sulfur-reducing bacteria, p. 663-679. In N. R. Krieg and J. G. Holt (ed.), Bergey's manual of systematic bacteriology, vol. 1. Williams and Wilkins, Baltimore. 